\title{
Pemberian Antitrombin III pada Sepsis Neonatal
}

\author{
Nathanne Septhiandi, Antonius Pudjiadi, Pustika Amalia \\ Departemen Ilmu Kesehatan Anak Fakultas Kedokteran Universitas Indonesia/RS Dr. Cipto Mangunkusumo, Jakarta
}

Latar belakang. Kadar antitrombin III (AT III) dalam darah rendah pada pasien sakit berat dan penurunan kadarnya berkorelasi dengan derajat penyakit. Fungsi AT III sebagai antikoagulan, mempunyai peran penting untuk mencegah disfungsi mikrovaskular dan mengakibatkan kerusakan multi organ pada sepsis. Namun, peran teurapetik AT III pada sepsis masih diperdebatkan.

Tujuan. Melakukan evaluasi apakah pemberian AT III pada sepsis neonatal berat memiliki prognosis yang lebih baik bila dibandingkan dengan plasebo.

Metode. Penelusuran pustaka database elektronik yaitu Pubmed, Highwire, Google dan Yahoo.

Hasil. Didapatkan 12 artikel yang dianggap relevan dengan rumusan masalah, terdiri atas 3 meta-analisis, 8 randomized controlled trial (RCT), dan 1 review. Hasil meta-analisis pertama menyatakan bahwa pemberian preparat AT III aman dan dapat ditoleransi dengan baik. Dilaporkan AT III menurunkan tingkat mortalitas 22,9\% pada hari ke-30 pasca intervensi. Hasil meta-analisis kedua mendapatkan pemberian AT III tidak menurunkan risiko mortalitas secara keseluruhan (RR 0,96, IK95\%: 0,89;1,03), dan meningkatkan risiko perdarahan (RR 1,52, IK95\%: 1,3;1,78). Hasil meta-analisis ketiga menunjukkan pemberian AT III mengurangi risiko mortalitas dalam 28 sampai 30 hari (OR 0,649, IK95\%: 0,422; 0,998). Risiko perdarahan pada kelompok AT III tidak berbeda signifikan dengan kelompok plasebo.

Kesimpulan. Secara statistik penggunaan AT III apabila dibandingkan dengan plasebo pada keadaan sepsis neonatal tidak memperbaiki prognosis dalam hal menurunkan tingkat mortalitas selama 28-30 hari. Walaupun demikian, tingkat mortalitas kelompok AT III lebih rendah dibandingkan dengan placebo. Sari Pediatri 2016;18(1):74-80

Kata kunci : sepsis neonatal, antithrombin III, plasebo, mortalitas

\section{Provision of Antithrombin III in Neonatal Sepsis}

Nathanne Septhiandi, Antonius Pudjiadi, Pustika Amalia

Background. Level of antithrombin III (AT III) will decrease in severely ill patients and has a strong correlation to the degree of disease severity. AT III is an endogenous anticoagulant that appears to have an important therapeutic role in the prevention of micro vascular dysfunction and multiple organ injury in sepsis. But therapeutic potential of AT III as an anti-sepsis therapy is still debatable. Objective. To evaluate the safety and potential efficacy of antithrombin III (AT III) in treatment of patients with sepsis in neonatal period compared to placebo.

Methods. Literature search using electronic data base: PubMed, Highwire, Google, and Yahoo.

Result. There are 12 articles related to the topic, consist of 3 meta-analysis, 8 randomized controlled trial (RCT), and 1 review. First meta-analysis showed that the administration of AT III was safe and well-tolerated. The results of the meta-analysis demonstrated a $22.9 \%$ reduction in 30-day all-cause mortality in patients treated with AT III. Second meta-analysis found that AT III compared to placebo in general does not reduce the mortality risk (RR 0,96,95\% CI 0,89;1,03) and treatment with AT III can increase the bleeding risk (RR $1,52,95 \%$ CI 1,3;1,78). The third meta-analysis showed that AT III could reduced mortality risk in 28 to 30 days since the intervention was given (OR 0,649, 95\% CI 0,422; 0,998). The risk of bleeding is not significantly different compared to placebo group.

Conclusions. Compared to placebo, AT III administration to neonates with sepsis, although does not significantly reduces the mortality in 28-30 days but the mortality rate was lowerin neonates who received AT III compared to placebo. Sari Pediatri 2016;18(1):74-80

Keywords: neonatal sepsis, antithrombin III, placebo, mortality.

Alamat korespondensi: Dr. Nathanne Septhiandi, SpA. Departemen Ilmu Kesehatan Anak Fakultas Kedokteran Universitas Indonesia/RS Dr. Cipto Mangunkusumo, Jakarta. E-mail: dr.nathanne@gmail.com 
A ntitrombin III (AT III) merupakan suatu preparat anti-koagulan alamiah dan memiliki sifat anti-inflamasi. Kadar AT III dalam darah turun $20 \%-40 \%$ pada pasien sakit berat dan penurunannya berkorelasi dengan derajat penyakit. Sepsis merupakan bentuk stres fisik yang sangat berat yang dapat mengakibatkan sekresi sitokin pro-dan anti-inflamasi serta mobilisasi leukosit dan aktivasi proses pembekuan. Selain memiliki efek antikoagulan, AT III juga memiliki dampak antiinflamasi yang diharapkan berguna pada keadaan tersebut. Interaksi AT III dan heparin yang merupakan terapi standar pada disseminated intravascular coagulation (DIC) perlu diperhatikan, karena heparin akan meningkatkan aktivitas AT III. ${ }^{1}$

Pemikiran untuk memutus rantai DIC dengan pemberian AT III sudah dimulai sejak tahun 1990, namun sampai saat ini masih menjadi perdebatan. Oleh karena itu, diajukan pertanyaan klinis sebagai berikut "Apakah pemberian preparat AT III pada sepsis neonatal berat memiliki prognosis yang lebih baik bila dibandingkan dengan plasebo?”

\section{Kasus}

Seorang bayi laki-laki, usia gestasi 35 minggu dengan berat lahir 1700 gram, lahir di IGD Rumah Sakit dr. Cipto Mangunkusumo (RSCM) secara sectio caesaria (SC) atas indikasi ibu mengalami preeklampsia berat dan gawat janin. Saat lahir bayi tampak lemah, ketuban berwarna jernih dengan jumlah cukup. Skor APGAR saat lahir 1/6/8. Pasien kemudian dirawat di special care nursery (SCN)-4 dengan diagnosis bayi prematur, respiratory distress ec hyalin membran disease (HMD) dengan tersangka sepsis. Maka dilakukan septic work up, foto dada dan analisa gas darah (AGD). Bayi diberikan continous positive airway pressure (CPAP) serta antibiotik amoksisilin klavulanat dan gentamisin.

Hari perawatan ke-2, pasien masuk neonatal intensive care unit (NICU) karena distres pernafasan semakin berat dan terjadi asidosis respiratorik. Pasien telah diintubasi dan diberikan ventilasi tekanan positif manual, saturasi perifer saat itu 86\%-91\%. Laju nadi pasien 144-156x/menit, bunyi jantung I dan II normal, akral teraba hangat, capillary refill time kurang dari 3 detik. Abdomen datar, lemas, dan bising usus normal, hepar dan lien tidak teraba, tungkai tidak edema.
Pasien tidak demam ataupun hipotermia, ratio netrofil imatur dan total (I/T) 0,18 dan CRP 0,18 mg/L. Didapatkan sonde lambung berisi cairan berwarna kecoklatan, tidak didapatkan perdarahan dari tempat

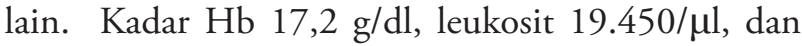
trombosit 243.000/ $\mu$ l. Selama perawatan di NICU pasien dipasang ventilator, mendapatkan dopamin karena pasien mengalami syok sepsis, antibiotik diganti menjadi piperacillin tazobactam dan amikasin.

Pada perawatan hari ke-24, terdapat perdarahan dari endotracheal tube (ETT), saat itu terdapat trombositopenia $(6.000 / \mu \mathrm{l})$, peningkatan prothrombin time (PT) 1,2x kontrol dan activated partial thromboplastin time (APTT) 1,5x kontrol. Pasien diberikan transfusi fresh frozen plasma (FFP) dan trombosit. Kadar prokalsitonin 34,54 ng/mL dengan CRP $175,9 \mathrm{mg} / \mathrm{L}$ hasil kultur darah (3 hari setelah diambil) menunjukkan Acinetobacter baumannii maka antibiotik diberikan sefepim.

Pada perawatan hari ke-30, terdapat perdarahan kembali dari ETT sedangkan sepsis masih berlangsung, sehingga dipikirkan terjadi DIC. Kadar antitrombin III menunjukkan penurunan 30\% (normal 80\%-120\%), disertai penurunan kadar fibrinogen $79,2 \mathrm{mg} / \mathrm{dL}$ (normal 136-384 mg/dL) dan peningkatan kadar d-dimer $2.400 \mu \mathrm{g} / \mathrm{L}$ (normal 0-300 $\mu \mathrm{g} / \mathrm{L}$ ). Preparat AT III diberikan pada pasien dengan dosis $100 \mathrm{IU} / \mathrm{kgBB}$ loading dose dilanjutkan dengan $50 \mathrm{IU} /$ $\mathrm{kgBB}$ selama 3 hari berturut-turut. Pada perawatan hari ke-34 terjadi perburukan, perdarahan masih berlangsung, disertai bradikardi dan desaturasi, akhirnya pasien dinyatakan meninggal di hadapan perawat dan keluarga.

\section{Metode penelusuran literatur}

Guna menjawab masalah klinis tersebut dilakukan penelusuran pustaka secara online dengan menggunakan instrumen pencari Pubmed, Highwire, Google, dan Yahoo. Kata kunci yang digunakan adalah sepsis, neonatus, antithrombin III, heparin, placebo, disseminated intravascular coagulation, dan mortality. Didapatkan 12 artikel yang dianggap sesuai dengan masalah, terdiri dari 3 meta-analisis, 8 randomized controlled trial (RCT), dan 1 review. Levels of evidence ditentukan berdasarkan klasifikasi yang dikeluarkan oleh Oxford Centre for Evidence-based Medicine levels of evidence ${ }^{2}$ 


\section{Hasil penelusuran}

\section{Studi meta-analisis (level of evidence I)}

1. Meta-analisis oleh Eisele $\mathrm{dkk}^{3}$ melibatkan 3 RCT yang meneliti tingkat mortalitas pada 122 pasien sepsis yang diberikan preparat AT III dibandingkan plasebo. Ketiga RCT ini tidak mencari ada tidaknya peningkatan risiko perdarahan pada intervensi tersebut dan tidak diberikan heparin secara bersamaan. Hasil metaanalisis menyatakan bahwa pemberian preparat AT III akan menurunkan tingkat mortalitas $22,9 \%$ pada hari ke-30 pasca intervensi. Ketiga uji klinis menggunakan dosis AT III yang berbeda-beda. Dua uji klinis menggunakan dosis AT III yang rendah dan satu klinis menggunakan dosis AT III yang tinggi. Risiko perdarahan akibat pemberian AT III tidak dijelaskan.

2. Studi Afshari $\mathrm{dkk}^{1}$ merupakan studi meta-analisis dari 20 uji klinis terkontrol dengan jumlah subjek 3458 pasien. Semua uji klinis tersebut berusaha membandingkan efektifitas pemberian AT III dengan plasebo, pada pasien dewasa maupun anak dengan kondisi sakit berat atau kondisi kritis, yang dirawat di Unit Perawatan Intensif. Dosis AT III yang digunakan bervariasi dan tidak memperhitungkan faktor pemberian heparin yang bersamaan dengan AT III. Hasil metaanalisis tersebut adalah pemberian AT III tidak menurunkan risiko mortalitas secara keseluruhan (RR 0,96, IK95\%: 0,89;1,03). Pemberian AT III juga meningkatkan risiko perdarahan (RR 1,52, IK95\%: 1,3;1,78).

3. Studi Wiedermann $\mathrm{dkk}^{4}$ merupakan studi metaanalisis dari 3 uji klinis terkontrol yang melakukan randomisasi terhadap pasien yang menerima preparat AT III atau plasebo. Sejumlah 364 pasien dengan sepsis berat dan syok septik yang disertai dengan DIC, dilakukan randomisasi untuk pemberian preparat AT III dengan dosis tinggi dan dosis rendah ${ }^{4,5}$ atau plasebo, tanpa menggunakan heparin. Hasil meta-analisis menunjukkan bahwa pemberian AT III mengurangi risiko mortalitas dalam 28 sampai 30 hari sejak pemberian preparat (OR 0,649, IK95\%: 0,422; 0,998). Komplikasi perdarahan hanya dijumpai pada satu uji klinis, tetapi risiko perdarahan pada grup pemberian AT III tidak berbeda signifikan dengan grup plasebo.

\section{Pembahasan}

Sepsis adalah suatu infeksi yang diikuti respon inflamasi sistemik tubuh [systemic inflamatory response syndrome = SIRS]. Sepsis berat adalah sepsis yang disertai dengan kerusakan multiorgan atau hipoperfusi jaringan. ${ }^{7}$ Pada keadaan SIRS, tubuh mengeluarkan sitokin= pro-inflamasi yang jika tidak segera teratasi dapat menyebabkan pasien jatuh ke dalam DIC dan sering berakhir dengan kematian. Terjadinya DIC dimulai dengan aktivasi sitokin pada jalur koagulasi secara sistemik sehingga terjadi consumptive coagulopati. ${ }^{3}$

Usaha untuk menghentikan proses DIC dengan menggunakan suplementasi AT III sudah dimulai sejak sekitar tahun 1990, tetapi masih diperdebatkan baik dalam hal luaran, dosis penggunaan, interaksi dengan heparin, dan efek samping penggunaan. Penelitian yang dilakukan oleh Inthorn $\mathrm{dkk}^{6}$ mendapatkan kadar AT III pada pasien sepsis turun sampai 60\% dan tanpa suplementasi dari luar, kadar tersebut akan tetap bertahan selama proses sepsis berlangsung. Seluruh subjek (15 pasien) mengalami DIC dan berakhir pada kematian, sedangkan pada kelompok intervensi dengan suplementasi AT III keadaan DIC dapat diatasi dan hanya 3 dari 14 pasien yang berakhir pada kematian.

Masalah yang sulit pada penggunaan AT III adalah kapan AT III harus diberikan pada pasien sepsis. Kienast $\mathrm{dkk}^{5}$ dalam penelitiannya membagi pasien sepsis menjadi 3 kelompok, yaitu kelompok tanpa DIC, non-overt DIC (lampiran 1), dan overt DIC (lampiran 2). Masing-masing kelompok diberikan intervensi dengan AT III atau plasebo. Intervensi AT III menggunakan dosis tinggi (dalam hal ini dosis awal 6000 IU dan dosis rumatan $1 \times 6000$ IU diberikan selama 4 hari, total dosis 3000 IU) tanpa pemberian heparin. Studi ini memperlihatkan penurunan tingkat mortalitas yang bermakna pada kelompok DIC, tetapi tidak pada kelompok tanpa DIC. Pada kelompok overt DIC, penurunan tingkat mortalitas secara statistik tidak bermakna yaitu 20\% dibandingkan 36,4\% pada hari ke-28 [0,55, IK95\%: 0,2;1,55, p>0,2] dan 30\% dibandingkan 4,9\% pada hari ke-90 [0,73, IK95\%: 0,32;1,69, $>>0,2]$. Pada kelompok non-overt DIC, penurunan tingkat mortalitas pasien secara statistik 
bermakna yaitu $25,7 \%$ dibandingkan $40,9 \%$ pada hari ke-28 [0,63, IK95\%: 0,43;0,92, p=0,023] dan 34,6 dibandingkan $51,8 \%$ pada hari ke-90 [0,67, IK95\%: 0,49;0,92, $p=0,014]$. Pemberian preparat AT III pada pasien dengan overt DIC tidak menunjukkan perbaikan klinis.

Wiedermann $\mathrm{dkk}^{4}$ membagi subjek penelitiannya berdasarkan derajat beratnya sepsis menurut simplified acute physiology score (SAPS II) (lampiran 3), yaitu stratum I [risiko sedang terhadap kematian $(<30 \%)$ ], stratum II [risiko tinggi terhadap kematian (30\%$60 \%)$ ], dan stratum III [risiko sangat tinggi terhadap kematian (>60\%)]. Pada masing-masing kelompok diberikan intervensi, baik dengan AT III atau plasebo. Penelitian tersebut juga memasukkan pasien yang menggunakan AT III dengan heparin dosis rendah. Hasil penelitian menunjukkan penurunan tingkat mortalitas yang bermakna pada stratum II pada kelompok yang tidak menggunakan heparin, yaitu pada observasi hari ke-56 yaitu 39,9\% dibandingkan $52,2 \%[0,764(0,593-0,984)]$ dan hari ke-90 yaitu $42,8 \%$ dibandingkan 55,1\% [0,776 (0,614-0,986)]. Sedangkan pada stratum I dan III penurunan tingkat mortalitasnya tidak bermakna secara statistik. Pasien stratum III sesuai dengan penelitian ini tidak berespon baik pada pemberian AT III.

Dosis dan cara pemberian AT III belum seragam, salah satu penelitian yang membandingkan dosis pemberian AT III adalah Sawamura dkk. ${ }^{7}$ Sawamura $\mathrm{dkk}^{7}$ membandingkan pemberian preparat AT III dosis tinggi (60 IU/kg/hari) dibandingkan dengan dosis rendah (30 IU/kg/hari) secara drip kontinu dalam waktu 1 jam selama 3 hari berturut-turut. Evaluasi prognostik dilakukan dengan menggunakan skor Japanese Association for Acute Medicine (JAAM) DIC (lampiran 4) untuk evaluasi skor sepsis/DIC. Hasil penelitian tersebut menunjukkan bahwa pemberian AT III dosis rendah dibandingkan dosis tinggi tidak memberikan hasil yang berbeda secara statistik, tetapi secara klinis terdapat perbaikan yang nyata pada kelompok yang diberikan suplementasi AT III dosis rendah. Selain itu, pada kedua kelompok tidak ditemukan efek samping perdarahan akibat pemberian AT III. Pemberian AT III juga perlu dihitung secara individual berdasarkan kadar AT III dalam darah saat itu dan berat badan pasien. ${ }^{8}$

Efek samping yang ditakutkan pada pemberian AT III adalah perdarahan. Efek tersebut juga dipikirkan dengan adanya interaksi dengan penggunaan heparin yang dipakai baik sebagai terapi standar dari DIC [dosis tinggi (>10.000 IU/hari)] maupun sebagai profilaksis terjadinya trombosis [dosis rendah(<10.000 IU/hari)]. Didapatkan bahwa perdarahan lebih sering terjadi pada kelompok yang mendapatkan AT III dosis tinggi, yaitu $22 \%$ dibandingkan $12,8 \%(\mathrm{p}<0,001)$ dan perdarahan lebih nyata pada kelompok yang juga mendapatkan terapi heparin pada berbagai dosis. ${ }^{11}$ Efek perdarahan pada penggunaan AT III dengan heparin masih kontroversial, tetapi jarang dilaporkan pada penggunaan AT III yang tidak dikombinasikan dengan penggunaan heparin. ${ }^{1,4,7-9}$

\section{Kesimpulan}

Secara statistik, penggunaan AT III apabila dibandingkan dengan plasebo pada keadaan sepsis tidak memperbaiki prognosis dalam hal menurunkan tingkat mortalitas selama 28-90 hari. Namun secara klinis, pasien sepsis neonatal yang diterapi dengan AT III memiliki tingkat mortalitas yang lebih rendah bila dibandingkan dengan plasebo, terutama pada penggunaan AT III yang tidak dikombinasikan dengan penggunaan heparin.

\section{Daftar pustaka}

1. Afshari A, Wetterslev J, Brok J, Moller A. Antithrombin III in critically ill patients: systematic review with meta-analysis and tral sequential analysis. BMJ 2007;335:1248-51.

2. Medicine OCoE-b. Oxford centre for evidence-based medicine levels of evidence. 2011.

3. Eisele B, Lamy M, Thijs L, Keinecke H, Schuster H, Matthias F, dkk. Antithrombin III in patients with severe sepsis. Intensive Care Med 1998;24:663-72.

4. Wiedermann CJ, kaneider NC. A systematic review of antithrombin concentrate use in patients with disseminated intravascular coagulation of sever sepsis. Blood Coagul Fibrinolysis 2006;17:521-6.

5. Kienast J, Juers M, Wiedermann C, Hoffmann J, Ostermann H, Strauss R. Treatment effects of highdose antithrombin without concomitant heparin in patients with severe sepsis with or without disseminated intravascular coagulation. J Thromb Haemost 2006;4: 90-7.

6. Inthorn D, Hoffmann JN, Harti WH, Muhlbayer D, Jochum M. Antithrombin III supplementation in severe sepsis: beneficial effects on organ dysfunction. Shock 
1997;8:328-34.

7. Sawamura A, Hayakawa SGM, Hoshino H, Kubota N, Sugano M. Effects of antithrombin III in patients with disseminated intravascular coagulation diagnosed by newly developed diagnostic criteria or critical illness. Clin Appl Thromb Hemost 2009;15:561-6.

8. Druglib.com [homepage on the internet]. New York: Company; c2006-2012 [diunduh pada 5 Desember 2013]. Thrombate III (Antithrombin III) - Indications and Dosage; [about one screen]. Dari : http://www. druglib.com/druginfo/thrombate-iii/indications_dosage/

9. Wiedermann CJ, Hoffmann Jn, Juers M, Ostermann $\mathrm{H}$, kienast J, Briegel J, dkk. High-dose antithrombin III in the treatment of severe sepsis in patients with a high risk of death: Efficacy and safety. Crit Care Med
2006;34:285-92.

10. Toh C, Hoots W. The scoring system of the scientific and standardisation committee on disseminated intravascular coagulation of the international society on thrombosis and haemostasis: a 5-year overview. J Thromb Haemost 2007;5:604-6.

11. Gall JL, Lemeshow S, Saulnier F. A new simplified acute physiology score (SAPS II) based on a European / North American multicenter study. JAMA 1993;270:2957-63.

12. Sawamura A, Hayakawa M, Gando S, Kubota N, Sugano M, Wada T, dkk. Application of the Japanese Association for Acute Medicine disseminated intravascular coagulation diagnostic criteria for patients at an early phase of trauma. Thromb Res 2009;124:706-10. 


\section{Lampiran 1.}

Sistem skoring nonovert $\mathrm{DIC}^{5,10}$

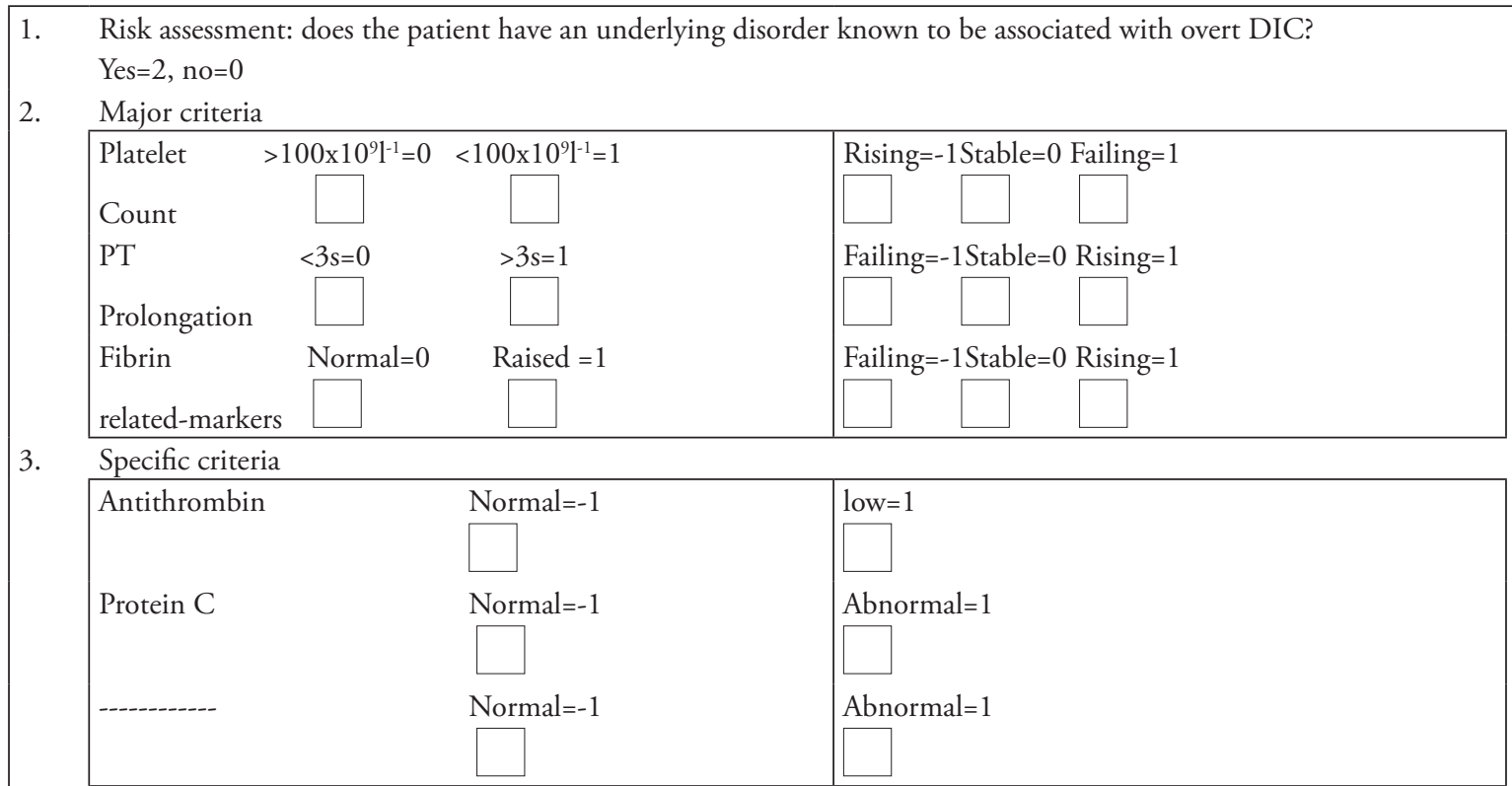

4. Calculate score

\section{Lampiran 2.}

\section{Sistem skoring overt $\mathrm{DIC}^{5,10}$}

1. Risk assessment: does the patient have an underlying disorder known to be associated with overt DIC?

If Yes: Proceed

If No: Do not use this algorithm

2. Order global coagulation tests (platelet count, prothrombin time, fibrinogen, fibrin-related marker)

3. Score global coagulation tests result

- Platelet count

$(>100=0 ;<100=1 ;<50=2)$

- $\quad$ Elevated fibrin related marker (e.g. D-dimers; fibrin degradation products) (no increase $=0$; moderate increase $=2$; strong increase $=3$ )

- $\quad$ Prolonged prothrombin time

$(<3 s=0 ;>3 s$ but $<6 s=1 ;>6 s=2)$

- Fibrinogen level

$$
\left(>1.0 \mathrm{gL}^{-1}=0 ;<1.0 \mathrm{gL}^{-1}=1\right)
$$

4. Calculate score

If $\geq 5$ : compatible with overt DIC: repeat score daily

If $\leq 5$ : suggestive (not affirmative) for non-over DIC: repeat next 1-2 days 
Lampiran 3.

Skoring SAPS II $^{11}$

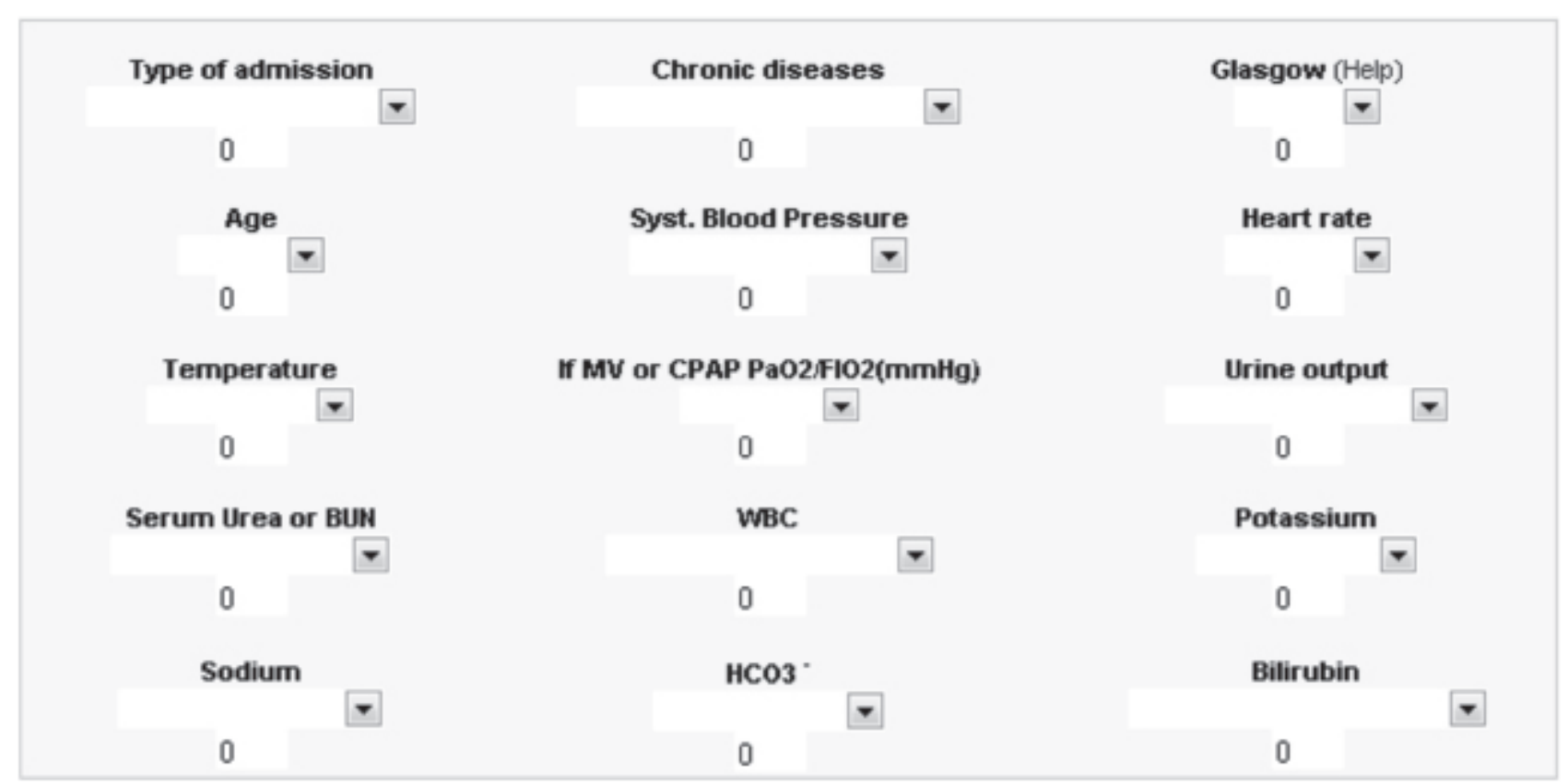

\section{Lampiran 4.}

Skoring DIC berdasarkan Japanese Association for acute Medicine (JAAM) ${ }^{12}$

\section{Systemic inflammatory response syndrome criteria}

$\geq 3$

$0-2$

Score

Platelet counts $\left(10^{9} / \mathrm{L}\right)$

$<80$ or more than $50 \%$ decrease within 24 hours

$>80<120$ or more than $30 \%$ decrease within 24 hours

$\geq 120$

Prothrombine time (value of patient/normal value)

$\geq 1.2$

$<1.2$

Fibrin/fibrinogen degradation products $(\mathrm{mg} / \mathrm{L})$

$$
\begin{aligned}
& \geq 25 \\
& 10<25 \\
& <10
\end{aligned}
$$

Diagnosis

4 points or more

Criteria for systemic inflammatory response syndrome

- $\quad$ Temperature $>38^{\circ} \mathrm{C}$ or $<36^{\circ} \mathrm{C}$

- Herat rate $>90$ beats $/ \mathrm{min}$

- Respiratory rate $>20$ breath / min or $\mathrm{PaCO} 2<32$ torr $(<4.3 \mathrm{kPa})$

- White cell blood counts $>12.000 / \mathrm{mm}^{3},<4000$ cells $/ \mathrm{mm}^{3}$, or $10 \%$ immature (band) forms 